\title{
Evaluating Mergers and Acquisition as Strategic Interventions in the Nigerian Banking Sector: The Good, Bad and the Ugly
}

\author{
B. E. A Oghojafor \\ Professor of Strategic Management, Department of Business Administration \\ Faculty of Business Administration, University of Lagos, Nigeria \\ Tel: 234-803-300-0522Ｅ-mail: akpoyomareo@yahoo.com \\ Sunday Abayomi Adebisi (Corresponding author) \\ Senior Lecturer in the field of Business Administration, Department of Business Administration \\ Faculty of Business Administration, University of Lagos, Nigeria \\ Tel: 234-802-826-3032Ｅ-mail: yommysun@yahoo.com
}

Received: November 17, 2011

Accepted: March 9, $2012 \quad$ Published: May 1, 2012

doi:10.5539/ibr.v5n5p147

URL: http://dx.doi.org/10.5539/ibr.v5n5p147

\begin{abstract}
This study evaluated Merger/Acquisition as an intervention strategy in the Nigerian banking sector. The objective was to identify whether this strategy has actually achieved the desired result for which it was purposed, especially, in the popular Nigerian merger of 2005. To this end, the study was carried out using both primary (questionnaire) and secondary (banks financial statements) data. 100 copies of questionnaire were administered on the management members of the sampled banks. From the three hypotheses that were tested; hypothesis 1 result revealed the calculated $t$-statistics $(\mathrm{t}=6.591 \mathrm{P}<0.05)$ signifying that, Merger/Acquisition had helped to curb the distress that would have occurred in the Nigeria banks during the period it was executed. Hypothesis 2 which measured performances in pre and post-merger showed that, the average capital of banks sampled in pre Merger period was N1433.20 million while post Merger period was N6358.76 million and the difference was statistically significant at 0.05 level $(t=6.755, \mathrm{P}<0.05)$. Profit recorded for pre Merger period was $\mathrm{N} 2192.48$ million while post Merger profit was N16839.12 million thereby creating significant differences between pre and post Merger profit which was statistically significant at 0.05 level $(\mathrm{t}=5.276, \mathrm{P}<0.05)$, implying that, banks performance in post Merger was significantly different from the performance before Merger. Hypothesis 3 evaluated whether bad corporate governance was responsible for this merger; the calculated $t$-statistics was $(t=3.197, \mathrm{P}<0.05)$ and it was decided that there would not have been need for merger if good corporate governance had been in place. Based on these findings, it was recommended that merger/acquisition should not be hastily implemented; rather, it should be carefully applied when the objective for the intending firms is to achieve synergy; and that, corporate governance should be given priority attention by both the regulatory agencies and shareholders so that erring bank directors can be sanctioned appropriately.
\end{abstract}

Keywords: Merger, Acquisition, Consolidation, Portfolio investment, Central Bank of Nigeria (CBN), Post-merger period, Intervention fund and corporate governance

\section{Introduction}

The Nigerian banking sector regulator; Central Bank of Nigeria (CBN) employed merger/acquisition as a consolidated instrument to correct the deficiencies in the financial sector in 2005. This was done under the leadership of the then CBN Governor; Professor Charles Soludo. The economic rationale behind this domestic consolidation policy as at this time was highly indisputable. The justifications being that, Nigeria as at this time had 89 banks with 3,382 branches predominantly situated in the urban centers as at June 2004 (Soludo, 2006). Besides, these branches were characterized by structural and operational weaknesses such as; low capital base, dominance of a very few banks, insolvency and illiquidity, overdependence on public sector deposits and foreign exchange trading, poor asset quality and weak corporate governance, low depositors' confidence, banks that could not effectively support the real sector of the economy and banking sector with credit to the domestic economy at $24 \%$ of GDP compared to African average of $87 \%$ and $272 \%$ for developed countries (Soludo, 2006). Given these bedeviled 
circumstances, it became sensible to ensure quick and spontaneous intervention strategies to save the system from total collapse. Therefore, the driving forces behind the consolidation (merger and acquisition) agenda included; better risk control, advancement of marketing and product initiatives, improvement in overall credit risk and technology exploitation, effective banking supervision, evolution of a strong and safe banking system, improved transparency and accountability, cost reduction and effective global competition, depositors' trust among other factors. These drivers were anticipated to improve the operational efficiencies and operations of the players in the banking sector that will survive the consolidation era. However, Forlong (1998) claimed that, merger and acquisition in the banking industry has had more impact on the structure rather than the performance which has been harder to discern. The decade (1995 and 2005) was particularly traumatic for the Nigeria banking industry, with the magnitude of distress reaching an unprecedented level, thereby making it an issue of concern not only to the regulatory bodies but also to the public. It was this that actually necessitated the need for an overhauling strategy of the entire financial system which made the CBN introduced a very major reform agenda that changed the banking landscape of the country in 2004. The reform was a 13 agenda reform which main thrust was the prescription of a minimum capital base of 25 billion Naira. This reform further led to merger and acquisition in the industry and scaled down the Nigeria banks from 89 to 25 and much later 24 . This study aims to evaluate the effects (positive and negative) that merger and acquisition as a consolidation strategy had had on the performance of banks in Nigeria since 2005. It is interested to measure the extent to which this twin strategy has fared among the emerged banks from the consolidation and the attendant effect on the nation's aggregate economy.

\section{Review of Literatures}

The decision of an organization to merger or acquire another is a decision that requires much deliberation and consideration. Some of the considerations must involve: why merger? What are the problems associated with merging? What benefits will the organization derive from the merger? However, merger and acquisition is the process by which a company acquires another company (Obuh 2003). However, Kay (1993) opined that mergers and acquisition often form part of the strategic options expected to transform company performances. In the opinion of Lynch (1997) he said that, mergers usually arise when neither company has the scale to acquire the other on its own weaker company; expansion can be created by entrepreneur that is already established through mergers agreement. He can merge with another company producing similar products to form a new strong identity that will be of a greater advantage to both. While in mergers both merging firms lose their registering name to becoming a new company entirely, acquisition involves the stronger organisation swallowing the smaller or weaker one entirely without the stronger firm changing its identity. Merger is simply the metamorphosing of two independent firms with different names into one single business entity emerging from the agreement. Merger actually has the capacity of bringing about synergy.

It is not an understatement to state that, the Nigerian banking reform exercise and consolidation between 2004 and December 2005 later ended up becoming a serious reflection of merger and acquisition. The reason being that, the major strategy of escaping the sledge hammer of the CBN (should the 25 billion Naira capital base not met) was for the banks to hurriedly pool their resources together to meet the book value of the minimum capital base. Since the essence of any reform is to bring about greater efficiency not only to the organizations but also their contributions to economic development of the nation, then it became important to raise a fundamental question in this study about whether the consolidation exercise (merger and acquisition) has impacted positively on the performance of the bank and the economy in general. Pautler (2001) opined that, the value gain that alleged to accrue to the larger and growing wave of merger and acquisition activity has not been verified. The adoption of financial reforms has often been postponed reversed shortly after being implemented or partially implemented for fear of recessionary consequence. In support of this statement, it is a known fact that, prior to 2005, bank distress had being a serious issue or problem which had made many citizens lost interest in the banking system without the regulatory authorities having the boldness to address it.

There is no doubt that, banks are lifeline of the economy of any country. They occupy central position in the country's financial system and are essential agents in the development process. By intermediating between the surplus and deficit savings units within an economy, banks mobilize and facilitate efficient allocation of national savings, thereby increasing the quantum investments and hence national output (Afolabi, 2004). Through financial intermediation, banks facilitate capital formation (investment) and promote economic growth. The banking industry in Nigeria has witnessed a remarkable growth, especially since the de-regulation of the financial services sector in the last quarter of 1986. In terms of headcount for instance, the number of banks increased by about $154.8 \%$ from 42 in 1986 to 107 in 1990. It further increased by about 12\% to120 in 1992. By 2004, however, the number had reduced to 89 . This was because some banks had to be liquidated on account of their dwindling fortunes. The number of bank branches also rose from 1,394 in 1986 to 2,013 in 1990; 2,391 in 1992 and by 2004 in spite of the 
reduction in number of banks, it had reached 3,100. This translated to an inter-temporal increases of $44 \%, 18.8 \%$ and $29.7 \%$, respectively. (Ebong, 2005)

Recapitalization in the banking industry has raised much argument among the bank regulators. Historically, the failure of pioneer 1930's and 1940's financial system brought about the enactment of banking ordinance of 1952. Banking ordinance of 1952 then prescribed an operating license and emphasized on minimum equity for all banks (Onoh, 2002). Since then, raising the banking capital has become the hallmark response policy of the Nigerian monetary authorities. Capitalization is an important component of reforms in the banking industry, owing to the fact that, a bank with strong capital base has the ability to absorb losses arising from non-performing liabilities (NPL). Attaining capitalization requirement is achieved through consolidation, convergence as well as the capital market. Thus, banking reforms are primarily driven by the need to achieve the objectives of consolidation, competition and convergence. (Deccan, 2004). In view of the low financial base of these 89 banks, they were encouraged to merge because out of the 89 banks that were in operation before reform, not more than ten of them were very strong. As a result of this, more than $80 \%$ (75) of them merged into 25 banks while 14 that could not finalize their consolidation exercise before the expiration of deadline were liquidated. To a large extent, this consolidation (merger and acquisition) was based on the proposition that there will be gains accruing from expenses reductions, increased market power, reduced earnings volatility and encourage economies of scale. In theory, merger is expected to enhance value by raising the level of bank diversification by either broadening the geographic reach of an institution or increasing the breadth of the products and service offered. Moreover, the simple addition of newly acquired assets and deposits were expected to facilitate diversification by increasing the number of bank customers. Greater diversification provides values by stabilizing returns while lower volatility may raise shareholder wealth in several ways. First, the expected value of bankruptcy costs may be reduced. Second, if firms face a convex tax schedule, then expected taxes paid may fall, raising expected net income. Third, earning from lines of business as a result of customers' value for bank stability which will necessitate more patronage.

\subsection{The Position of the Banks Immediately after Merger/Acquisition}

There were glowing performances immediately the consolidation exercise was concluded in the Nigerian Banking sector. For example, in the case of Skye bank two years after the consolidation era, it received a positive rating from a financial analysis firm; RTC Strategy and Advisory in 2008, which described the bank's current performance as being achieved on some strategic realities coming out from the mergers of five banks namely; Prudent Merchant Bank Plc., EIB International Bank Plc., Bond Bank Ltd., Reliance Bank Ltd and Cooperative Bank Plc. Skye bank's financial performances for the year ended 2008 showed that, it crossed the 1 Trillion mark in total assets and achieved a profit before Tax of N 21billon ( RTC Strategy and Advisory, 2008). According to the analyst, the bank's ratio of non-performing loans steadily reduced from 22.60 percent in 2006 to 5.34 percent in 2007 and 3.70 percent in 2008 , indicating an improved asset quality. It was also noted by the analyst that, the Skye bank's net earnings increased by an average of $65 \%$ over the last three years, with net interest margins at $58.96 \%$ percent which was seen as very strong. Return on average assets equally steadily improved from $1.98 \%$ in 2006 to $2.07 \%$ in 2008 . On technology and development payment channels, the analyst noted that the bank was clearly punching above its weight, having become known as the bank whose Automated Teller machine (ATM) always works.

Similarly, examining Wema bank Plc which acquired National Bank Plc during the consolidation era revealed an immediate tremendous change since the last reform. Some of the benefit as appraised by the analyst included branch network increased, total deposits grew by $157 \%$ from N32.78 billion to N84.28 billion in 2006, total assets base increased by $203 \%$ from N44.1 to N133.6 billion, shareholders' fund stood at N26.2 billion as at $31^{\text {st }}$ December. 2005 after the consolidation; a growth of $595 \%$, gross earnings increased by $89.4 \%$, the bank was then ranked among the top 10 banks in Nigeria because all the 110 branches as at 2006 were fully connected real time on line. (See Table 1)

Examining the immediate post-merger performance of the United Bank for Africa (UBA) also revealed ground breaking record of a balance sheet size of N1.05 trillion, for its financial year ended, September 30, 2006 (Annual Report 2006). UBA bank Plc emerged after the consolidation from the merger with Standard Trust Bank Plc. Despite huge interpretation cost associated with the successful merger, which included interpretation, harmonization of staff salaries and a voluntary exit programme, the bank posted a healthy profit of N12.8 billion. The bank management even stated that without the attendant merger costs which UBA had prudently decided to absorb in one financial year, the bank's profit would have been much higher. The bank then quickly declared a dividend of N1 per share, which was the highest ever in its history, plus a bonus of 1 share for every 10 shares currently held. Besides, UBA's annual account showed that the bank's deposit base soared 278\% from N 205 billion in 2005 to N776 billion in 2006, with gross earnings rising by $247 \%$ from N26.1 billion in 2005 to N90.27 billion in 2006 which was seen as unprecedented results. 
Intercontinental Bank was the same success story after consolidation having acquired Gate Way Bank, Equity Bank of Nigeria and Global Bank. It also witnessed tremendous change after the merger and acquisition. Its half year gross earnings grew by $149 \%$ from N13.62 billion in the corresponding period in 2005 to N33.93 billion in Q2-2006 while profit after tax rose to N6.34 billion from N3.32 billion in Q2-2005, an increase of 91\%. Soon after this, the third quarter (Q3-2006) result was released with more promising future as gross earning stands at N59.1 billion and profit after tax equal to N10.1 billion, translating a quarter-on-quarter growth of $94 \%$ and $84 \%$ respectively over the corresponding period in 2005. (Annual Report, 2006; see Table 2)

However, Afri-bank was not left out, its profit after Tax in 2007 was N6.93 billion with total asset of over N182 billion (Afribank Financial Statement, 2007)

\subsection{Were These Performances Sustained?}

The tragedy that befell the Nigerian banking sector was as a result of the over-blowing performances immediately after the merger which did not actually allow for caution to be taken by the banks. Given the results presented above, a quick conclusion could have been drawn that the strategic intervention of merger and acquisition worked the magic that the Nigerian banking sector needed during the period under review. But shortly after the consolidation exercises, the World experienced the global economic melt-down which was an acid test for the various consolidated banks in Nigeria. The weaknesses of the various mergers and acquisitions were blown open in Nigeria immediately the world entered the centre of the economic meltdown. The global financial crisis began in the United States of America and the United Kingdom at a point when the global credit market came to a stand-still in July 2007 (Avgouleas, 2008). Unfortunately for the Nigerian banks, this time was the period most of them were trying to justify the consolidation exercise in Nigeria. Many of these banks were posting very huge profits to actually show the success of the consolidation exercise (by way of merger and acquisition) when the global economic melt-down struck.

The financial crises that hit the entire world included stock market crashes and the bursting of other financial bubbles, currency crises, and sovereign defaults (Kindleberger \& Aliber, 2005; Laeven \& Valencia, 2008). The world economists attributed the cause of this crisis to a number of factors which include; housing and credit markets, which developed over an extended period of time. Some of these include: the inability of homeowner to make their mortgage payments, poor judgement by the borrower and/or lender, speculation and overbuilding during the boom period, risky mortgage products, high personal and corporate debt levels, financial innovation that distributed and concealed default risks, central bank policies, and regulation (Stiglitz, 2008). Similarly, Avgouleas (2008) enumerated the causes of the crisis as: breakdown in underwriting standards for subprime mortgages; flaws in credit rating agencies' assessments of subprime Residential Mortgage Backed Securities (RMBS) and other complex structured credit products especially Collaterized Debt Obligations (CDOs) and other Asset-Backed Securities(ABS); risk management weaknesses at some large US and European financial institutions; weak regulatory policies, including capital and disclosure requirements that failed to mitigate risk management weaknesses.

At the initial stage of this economic crisis, the Central Bank of Nigeria, the Finance Ministry as well as other government commentators argued that Nigeria economy was partially insulated from the direct effects of the financial crisis. But, as the nation's economy is integrated with that of the US and the UK to a greater extent, in no mean time, Nigerian financial system began to feel the heat of the indirect impacts of the crisis. Specifically, the financial system was affected in the areas of foreign direct investment (FDI) and equity investment which came under very serious pressure. Also, withdrawals of portfolio investment as a result of contagion effects began to cause a reduction in stock prices which eventually led to the crash of global stock and the Nigerian stock market. The crisis equally led to the downward trend in oil price which put further downward pressure on crude oil prices; this adversely affected the liquidity of the banking sector of the nation because the country depends on revenue from oil to finance its budget and the countries that were mostly hit by the crisis were the primary market for Nigerian oil. For instance, commercial lending came under pressure in developed countries and banks were unable to lend as much as they have done in the past as a result of bad margin loans that bedevilled all the Nigerian banks.

Immediately after the consolidated banks posted these stupendous financial results in year-end 2008, the crisis that swept away five managing directors in a day as a result of bad management and falsification of banks' financial performances began. The Central Bank of Nigeria (CBN) under the leadership of Mallam Sanusi Lamido Sanusi conducted an examination of the books of 10 banks jointly with the Nigerian Deposit Insurance Corporation (NDIC). What was found out was very alarming. It was discovered by CBN and NDIC that 5 out of the 11 banks were deep-down in financial crisis. The banks were; Intercontinental Bank, Union Bank, Finland Bank, Afri-Bank and Oceanic Bank. All these banks were among banks that claimed a very huge performance in the year-end 2008. The apex bank (CBN) had to quickly intervene by sacking the five Managing Directors on $14^{\text {th }}$ August, 2009. They 
included: Dr. Erastus Akingbola (Intercontinental); Dr. Barth Ebong (Union Bank); Mr. Okey Nwosu (Fin-Bank); Mr. Sebastian Adigwe (Afri-bank); and Mrs. Cecilia Ibru (Oceanic bank). These Managing Directors were further handed over to Economic and Financial Crimes Commission (EFCC) for further prosecution. In justifying this action, the CBN Governor (Mallam Sanusi Lamido) and Deputy CBN Governor Operations (Babatunde Lemo) revealed to Nigerians that, it was margin loans that got banks into trouble as a result of banks' exposure to the capital market. The CBN said, eleven of the 24 banks in the country are carrying the burden of N421.7 billion as margin lending including loans to individuals, stockbrokers or loans to corporate bodies backed by share certificates. CBN put the total estimate of the facilities banks granted individuals, stockbrokers as well as lending secured with share certificates at N1.2 trillion. It further reiterated that, available figures show that the top 11 banks in the country granted a total of N229.9 billion to individuals and corporate bodies as facilities to purchase shares. A breakdown of the data indicated that Intercontinental Bank tops the list of banks with heavy exposure to margin loans of N85.2 billion. The amount was said to be made up of N36.9 billion facilities granted to individuals and stock brokers and a total of N 48.3 billion granted to other corporate entities who used share certificate as collateral. It was followed closely by GT Bank which had a total margin loan portfolio of N70.3 billion made up of N18.9 billion loans to individuals and stock brokers to buy shares and N51.4 billion to other corporate entities who used share certificate as collateral. In CBN analyses, it further mentioned Eco-bank as third in the high profile margin loan saga with a margin loan exposure of N59.2 billion. First Bank was not left out, it had a total share loan exposure of N58.8 billion, but its balance sheet showed that it did not join the race for granting margin loans during the share boom years to individuals and stock brokers but corporate bodies that used share certificates as collateral. Others were: Access Bank Plc, with a total exposure of N33.5 billion of which N20.1 billion is as a result of loans granted to individuals and stock brokers for share trading while N13.4 billion was granted to other corporate entities which backed up the loans with share certificates; Oceanic Bank Plc, which granted a total of N22 billion as facilities for share trading to individuals and stock brokers; United Bank of Africa with a loan portfolio of N21.6 billion backed by share; Diamond Bank with a balance sheet total of N20.2 billion margin loans portfolio made up of N19.6 billion granted to individuals and stock brokers and N0.6 billion granted as facilities to other corporate bodies with share certificate as collateral; Union Bank, with a total of N17.8 billion margin loan facilities; Stanbic/IBTC bank with a total of N10.1 billion made up of N5.2 billion granted for share trading while N4.9 billion was granted to other corporate bodies backed with share certificates. (CBN Governor Press Briefing on the Managerial Restructuring and Developments of some Nigerian Commercial Banks, $14^{\text {th }}$ August, 2009)

It was amazingly revealed from the investigation that, transparency was weak in Nigeria. With the exception of Guarantee Trust Bank (GTB), bank financial statements were only presented in local GAAP (Generally Accepted Accounting Principles). However, Nigerian GAAP do not require the same levels of detailed disclosure as IFRS (International Financial Reporting System), which always made most Nigerian banks not to provide supplementary information of their Tier-1 and total capital adequacy ratios and detailed information regarding their loan portfolios in their annual reports. During the period under review by the CBN, First Bank was the only bank in the sector that disclosed its share lending exposure at end 2008 in its annual report. Share backed and margin lending were features of many Nigerian banks over the past two years before this examination was conducted. The CBN estimated sector wide exposure to this type of lending to be about N200 trillion at end 2008 which CBN said represented 30 per cent to 45 per cent of system wide share holder funds in 2008. Of this amount, the CBN estimated that about N400 billion related to margin lending. These facilities were primarily to individuals and stock brokers for the purpose of acquiring shares. After this exposure that revealed that all the performances after the consolidation were window dressed, the CBN then required all banks to make appropriate provision for non-performing loans and disclose them so that at the end of that quarter, all banks would have cleaned up their Balance Sheets.

The ugly part of this scenario is the facts that, most of these emerged banks (from the consolidation exercise) are presently among the troubled banks. After the exercise of the examination of the 10 banks in 2009, the second round that examined 11 banks found out many more non-performing loans and insiders' abuse. This led to the sack of Bank PHB and Spring bank Managing Directors and finally the revocation of licenses and nationalization of the three most troubled banks namely; Bank PHB (Now key Stone Bank Ltd), Spring Bank (Now Enterprise Bank Ltd) and Afri-Bank (Now Main-Street Bank Ltd). They were on $5^{\text {th }}$ August, 2011 handed over to Asset Management Corporation of Nigeria, (AMCON), through a nationalization process designed by Central Bank of Nigeria, (CBN) to protect depositors money. However, $30^{\text {th }}$ September, 2011 was set as deadline for weak banks to recapitalize in Nigeria for the country to possibly experience a new era in the banking industry. The earlier five rescued banks, viz: Oceanic Bank International Plc, Finbank Plc, Union Bank of Nigeria Plc, Equitorial Trust Bank Limited (ETB) and Intercontinental Bank Plc were lucky to scale through by securing core-investors. Oceanic Bank is operating under a Transaction Implementation Agreement (TIA) with Ecobank Transnational Incorporated (ETI); Union Bank sealed another merger deal with African Capital Alliance Consortium; Fin-bank acquired again by First City Monument 
Bank; Intercontinental bank acquired by Access Bank and Equitorial Trust Bank acquired by Sterling Bank Plc. in just about 5 years after the first consolidation exercise (through mergers and acquisitions) there was a compulsory need for anther consolidation to rescue the nation's banking sector. "THE BIG QUESTION IS": if the first consolidation exercise did not work, what is the assurance that this repeated exercise will make a significant difference? However, the CBN Governor is very hopeful that the crisis in the banking sector would be over by $30^{\text {th }}$ September, 2011; the last date, all commercial banks must have been capitalized with very strong liquidity rate and very low non-performing loans (NPL) to ensure efficiency in their operations. So was the 2005 consolidation exercise CBN Governor (Professor Charles Soludo) was so hopeful. It is hoped that, the good of this strategic exercise will be witnessed in Nigeria now and not the bad nor the ugly. However, world record still showed that only 1 out of 3 mergers always succeed after the merging exercise. The 2005 Nigerian Banking Sector Consolidation exercise did not even record this percentage (i.e. 33.3\%). Virtually all the consolidated banks through mergers and acquisition have failed in the sector. The very few banks that have been adjudged to be a bit healthy like First Bank, Zenith Bank, and Guarantee Trust Bank did not engage their strategic positioning during the consolidation exercise in 2005 by ways of merger and acquisition. Instead, they recapitalized with maximum assurance to their shareholders of their readiness to ensure quality return on shareholders' wealth. This therefore put a big question mark on the possibility of merger and acquisition being the strategic solution to the Nigerian turbulent banking sector.

\section{Methodology}

In carrying out empirical investigation on this study to actually measure (statistically) the significance of merger and acquisition as an intervention strategy in the banking sector, the authors purposively selected five banks for survey (i.e. Intercontinental bank, Skye bank, Afri-bank, Wema bank and United Bank of Africa). Besides the survey study which was carried out by the use of primary data (questionnaire), the authors went ahead to examine and analyze the books of these selected banks. Data (secondary) were extracted from the financial records of the banks for analyses by considering financial records of ten years; comprising of five-year financial record before the recapitalization/consolidation exercise (that brought about merger and acquisition) and five-year financial record after the merger and acquisition strategy has been consummated. Twenty (20) copies of the questionnaire were randomly administered on the management staff of each of these banks making a total of hundred (100) copies. However, Eighty-seven (87) copies were returned by the respondents signifying $87 \%$ administration success. In analyzing the data (both primary and secondary) Ordinary Least Square (OLS) and t-test methods were used. Collated data were analyzed by the use of tables for classification purpose and OLS used in measuring the linear association between a dependent variable $(\mathrm{Y})$ which is predictive and independent variable $\mathrm{X}$ which is the predictor (i.e. $\mathrm{Y}=\mathrm{a}+\beta 0 \mathrm{X}$, where: $\mathrm{Y}=$ dependent variable; $\mathrm{X}=$ independent variable; and ' $\mathrm{a}$ ', $\beta 0=$ are constants)

\subsection{Hypotheses, Models Specification and Results}

The following hypotheses and models were formulated to consider the empirical investigation carried out on this study and the results are equally presented:

\subsubsection{Hypothesis One}

Merger and acquisition as a strategic intervention has not significantly curb distress in Nigeria banking sector.

The regression model to test this hypothesis is formulated thus:

$$
\begin{gathered}
\mathrm{DTR}=\mathrm{f}(\mathrm{MCQ}) \\
\text { i.e } \mathrm{DTR}=\mathrm{b}_{0}+\mathrm{b}_{1} \mathrm{MCQ}+\mathrm{U}_{1},
\end{gathered}
$$

Where: DTR $=$ Distress in Nigeria banks; $M C Q=$ Merger and Acquisition, and $\mathrm{U}_{1}=$ Stochastic Error term.

\section{Results: (see Table 3)}

$\mathrm{DTR}=-9.514+.281 \mathrm{MCQ}+\mathrm{U}_{1}$

Std. Error $=(2.389)(.043)$

$\mathrm{t}=(-3.983)(6.591)$

$\mathrm{R}=.582, \mathrm{R}^{2}=.338, \mathrm{R}^{2}=330, \mathrm{~F}=43.446, \mathrm{DW}=2.217$

The result presents the effect of Merger and Acquisition on curbing distress in Nigeria banks. The result showed that, calculated $t$-statistics $(t=6.591)$ for parameter MCQ is greater than tabulated $t$-statistics $(t=1.980)$ at 0.05 level of significance. The coefficient of MCQ in the estimated regression model is .281 which implies that $28 \%$ of the decrease in DTR was accounted for by the MCQ. The coefficient of determination $\left(\mathrm{R}^{2}\right)$ is .338 indicating that $34 \%$ of variation in DTR is caused by variation in MCQ. The remaining $66 \%$ unexplained variable is largely due to 
variation in other variables outside the regression model which are otherwise included in the stochastic error term. The relationship between DTR and MCQ is moderately high, positive and statistically significant at 0.05 level $(\mathrm{t}$ $=.582, \mathrm{P}<0.05)$. The Durbin-Watson statistics is 2.217 which showed that autocorrelation is absent in the regression model. The overall regression model is statistically significant in terms of its overall goodness of fit ( $\mathrm{f}=$ 43.446, $\mathrm{P}<0.05)$. As a result of this the study accepts the alternatively hypothesis $\left(\mathrm{H}_{1}\right)$ meaning that Merger and Acquisition had helped to curb distress in Nigeria banks.

\subsubsection{Hypotheses Two}

There is no significant difference between the performance of banks before the merger and the post-merger period.

In conducting this test, the performances of banks were compared on the basis of their capital and profit before and after Merger using independent sample t-test statistics at 0.05 alpha level. (see Table 4)

Table 4 presents the performances of the banks before and after Merger periods. The result showed that, the average capital of banks sampled in pre-Merger period was N1433.20 million while post-Merger period recorded average capital of N6358.76 million. Therefore, the mean difference between Pre-Merger and Post-Merger period was statistically significant at 0.05 level $(t=6.755, \mathrm{P}<0.05)$. Similarly, the sampled banks recorded average profit of N2192.48 million during the pre-Merger period while the post-merger period increased significantly to N16839.12 million. The mean difference between banks' profit in pre-merger and post-merger periods was equally statistically significant at 0.05 level $(t=5.276, \mathrm{P}<0.05)$. Therefore, the alternative hypothesis $\left(\mathrm{H}_{1}\right)$ was accepted which implied that, banks' performance in post-Merger was significantly different from the performances before Merger.

\subsubsection{Hypotheses Three}

Bad corporate governance is not responsible for the forceful consolidation exercise in the Nigerian banking sector in 2005 and the recent one in 2011.

The regression model is specified thus:

$$
\begin{gathered}
\mathrm{BCG}=\mathrm{f}(\mathrm{MCQ}) \\
\mathrm{BCG}=\mathrm{b}_{0}+\mathrm{b}_{1} \mathrm{MCQ}+\mathrm{U}_{1}
\end{gathered}
$$

Where: $\mathrm{BCG}=\mathrm{Bad}$ Corporate Governance; $\mathrm{MCQ}=$ Merger and Acquisition; $\mathrm{U}_{1}=$ Stochastic Error term.

\section{Results: (see Table 5)}

$\mathrm{BCG}=-7.959+1.059 \mathrm{MCQ}+\mathrm{U}_{1}$

Std. Error $=(18.533)(.331)$

$\mathrm{t}=(-.429)(3.197)$

$\mathrm{R}=.328, \mathrm{R}^{2}=.107, \mathrm{R}^{2}=.097, \mathrm{~F}=3.197, \mathrm{DW}=0.207$

The result above measured whether bad corporate governance was responsible for the compulsory merger and acquisition in 2005 and the one being currently consummated in 2011 . The result revealed that, calculated t-statistics $(t=3.197, P<0.05)$ was greater than tabulated $t=$ statistics $(t=1.980)$ at 0.05 level of significance. The coefficient of determination $\left(\mathrm{R}^{2}\right)$ was 0.107 which implied that $11 \%$ of the variation in BCG was caused by variation in MCQ. The remaining $89 \%$ unexplained variation is caused by other variables outside the regression model which are otherwise included in the stochastic error term. The relationship between BCG and MCQ is low and positive but statistically significant at 0.05 alpha level $(\mathrm{r}=.328, \mathrm{P}<0.05)$. The Durbin Watson statistic was 0.207 which implied that autocorrelation exists in the model. However, the regression model is statistically significant in terms of its overall goodness of fit $(\mathrm{F}=10.221, \mathrm{P}<0.05)$ hence the alternative hypothesis was accepted. This implied that, bad corporate governance was actually responsible for the 2005 hasty merger and the one being currently executed in the banking industry in Nigeria.

\section{Conclusion}

This study has combined theoretical and empirical investigations to evaluate the intervention roles of merger and acquisition strategy in repositioning the ailing banking sector in Nigeria. However it was discovered that, the merger and acquisition that was consummated in 2005 only addressed the dangerous position of the nation's banking sector then in a 'fire-brigade' approach. Immediate results after the consolidation were only window-dressed success that eventually did not last. However, the Enron Corporation saga in 2001 made a repeat of itself in Nigeria after the consolidation. As highlighted in this study, the various posted financial results of the banks made many Nigerians to borrow fund from them (the banks) to pursue the acquisition of banks' shares. This eventually led to the demise of many when the actual status of the banks was revealed in 2009; the shock that the economy has not recovered from 
up till date. This study actually tested three hypotheses; from the tests, it was evident that, merger and acquisition was able to rescue the banks from the brink of collapse in 2005 and that, financial indices showed an improved performance after the merger. But this did not translate into fulfilling the objective of repositioning the banking sector for effective performance for the aftermath effect of the consolidation exercise was another round of failure that has led to the recent merger and acquisition of the rescued banks. The last hypothesis actually provided answer to our curiosity for it established that, bad corporate governance was what necessitated the 2005 fire-brigade merger and acquisition; the marriage of many strange bed fellows.

\section{Recommendations}

In view of the findings from this research, the following are hereby suggested:

Merger/acquisition is a strategic tool that must be cautiously applied and implemented. The maturation period of the merger must be allowed so that the financial records of the intending firms coming together can be properly scrutinized by the board of directors of each firm and the regulatory agencies. Merger/acquisition is supposed to be an intention of which either of the parties to the merger/acquisition can opt-out if hanky-panky (fraud or deceit) is discovered as being perpetuated. Merger/acquisition is supposed to be consummated when organisations want to leverage on the benefit of synergy and not a strategy to escape liquidation or meet statutory requirements to still continue to exist even with toxic assets which was the type of 2005 merger/acquisition. Therefore, Central Bank of Nigeria (CBN) and other regulatory agencies should take caution in rushing the ailing banks into another compulsory merger/acquisition. The process this time around should be painstakingly scrutinized to ensure that the emerged balance sheet of the new firm from the merger/acquisition is not doctored nor containing ghost financial figures that will further deceive the investors and injure our economy after the consummation.

It was evident from this study that $a b$ initio, there would not have been need for the 2005 forced merger/acquisition if the various banks have gotten their corporate governance right. As a matter of fact, insiders' abuse and bad financial management were responsible for weaknesses of the 89 banks before 2005 that merged into 25 banks and later 24 banks. Corporate governance is regarded as a system of checks and balances so that value is created by the organization in ethical ways to ensure that firms achieve their strategic objectives and meet their specified obligations in the most appropriate manner. Good corporate governance therefore, should be enforced by the regulatory agencies with stringent penalties. This will definitely build financial confidence that will help the firms to achieve their strategic objectives, and that of the shareholders. Good corporate governance is enough a strategy to enhance desired productivity and performance in the banking sector if all the cow-boys directors who do not uphold the tenets and fundamental principle of banking are shown the way out to pave way for an effective and efficient banking sector in Nigeria.

Finally, since the board of directors are responsible for implementing corporate governance in any firm, the shareholders should better organise themselves (with their votes) to always ensure selections that will respect integrity, professionalism, probity and accountability. Complete end should come to an era of very powerful Managing Directors that can put the banks in their pockets. To avoid controversies that trailed the sack of the five managing directors by CBN in 2009, shareholders should be alive to their responsibilities by protecting their wealth through spontaneous reaction (in the future) to any banks' Managing Directors that are found culpable of bad corporate governance. This will rather save us from hastily approaching merger/acquisition without a specific objective.

\section{References}

Afolabi, J. (2004). Implication of The Consolidation of Banks for the Nigeria Banking System in Elumilade, D 2010; Merger and Acquisition and Efficiency of Financial Intermediation in Nigeria banks. An Empirical Analysis.

Ajayi, M. (2005). Banking Sector Reform and Bank Consolidation: Conceptual Framework. Bullion, 29(2).

Aluko, T. (2002). Strategic Management and Business policy, Lagos-Nigeria. Afusco Printers and Publishers.

Avery, C., \& Zemsky, P. (1998). Multi-dimensional uncertainty and herd behaviour in financial markets. American Economic Review, 88, 724-748.

Avgouleas, E. (2008). Financial regulations, behaviour finance and the financial credit crisis in search of a new regulatory model. Retrived from www.papers.ssrn.com.

C.B.N. (2005). Guidelines and Incentives on Consolidation in Nigeria Banking Industry, Press Release, April 11, 2005 on Banking sector.

CBN Governor Press Briefing on the Managerial Restructuring and Developments of Some Nigerian Commercial banks, $14^{\text {th }}$ August, 2009. 
Chari, V., \& Kehoe, P. (2004). Financial crises as herds: Overturning the critiques. Journal of Economic Theory, 119, 128-150. http://dx.doi.org/10.1016/S0022-0531(03)00225-4

Cipriani, M., \& Guarino, A. (2008). Herd behavior and contagion in financial markets. The B.E. Journal of Theoretical Economics, 8(1) (Contributions), Article 24, pp. 1-54.

Forlong, F. (1998). New view of bank consolidation. FRBSF Economic letter, July 24.

Hameed, A. (2006). How Corporate Governance Affects Strategy of Corporations. (Unpublished Masters Thesis). Department of Management and Economics, Linkopin University, Sweden.

Hughes, J., Lang, W., Master, L., \& Moon, C. (1998). The dollars and sense of consolidation. Working Paper No, 98-100, Federal Reserve Bank of Philadephia.

Imala, O. (2005). Challenges of Banking Sector Reforms and Bank consolidation in Nigeria. Bullion, 29(2).

Kindleberger, C., \& Aliber, R. (2005). Manias, Panics, and Crashes: A History of Financial Crises (5th ed.). London: Wiley Incorporation. http://dx.doi.org/10.1057/9780230628045

Lynch, R. (1997). Corporate strategy. London: Pitman Publishing.

Markides, C. (1997). To Diversify or Not to Diversify, Boston. Harvard Business Review, 75(6), November-December.

Nicole, D. (2003). Bank consolidation internationalization and conglomeration: Trends and implications for financial risk. IMF working paper.

Ojo, J. (2005). Central Banking and Financial Sector Management in Nigeria: an Outsider View. In O. O. Fakiyesi and S. O. Akano (Eds.), Issues in Money, Finance and Economics Management in Nigeria (Essays in Honours of Professor Obasanmi Olakankpo).

Omoh, G., \& Egwuatu, P. (2009). Margin Loans that Cost MDs Their Jobs. Nigeria The News, August 15.

Osuala, F. (1991). Introduction to Research Methodology. Ibadan: African Fep Publisher Ltd.

Pautler, P. (2001). Evidence on Mergers and Acquisition. Bureau of Economics Federal Trade Commission, Working Paper.

Schenk, H. (2000). Mergers Efficiency Choice and International Competitiveness. Cheltenhan: Edward Elgar.

Soludo, C. (2004). Consolidation in the Nigeria Banking Industry to Meet the Development Challenges of the $21^{\text {st }}$ Century. Being an address delivered to the special meeting of the Banker Committee, held on July 26, at the CBN Headquarters, Abuja.

Soludo, C. (2007). Macroeconomics, Monetary and Financial Sector Developments in Nigeria. CBN website. www.cenbank.org.

Somoye, R. (2008). The Performance of Comercial Banks in Post-Consolidation Period in Nigeria: An Empirical Review. European Journal of Economics, Finance and Administrative Sciences, 62-73.

Udeme, C. (2011). A New Banking Era after September 30. Nigeria, Vanguard October, $2^{\text {nd }}$. www.sbp.or.pk/press/2003/corporategovernance/13102003.pdf

Table 1. Five-year annual financial statements summary of Wema Bank

\begin{tabular}{|c|c|c|c|c|c|}
\hline & $\begin{array}{l}2006 \\
\text { \#billion }\end{array}$ & $\begin{array}{l}2005 \\
\text { \#billion }\end{array}$ & $\begin{array}{l}2004 \\
\text { \#billion }\end{array}$ & $\begin{array}{l}2003 \\
\text { \#billion }\end{array}$ & $\begin{array}{l}2002 \\
\text { \#billion }\end{array}$ \\
\hline Total assets & 133.60 & 97.91 & 71.42 & 61.32 & 44.10 \\
\hline Deposit liabilities & 84.28 & 61.28 & 55.07 & 43.76 & 32.78 \\
\hline Loan $\$$ advance & 70.73 & 57.99 & 42.31 & 24.63 & 18.25 \\
\hline Current assets & 45.04 & 40.17 & 27.07 & 35.02 & 24.50 \\
\hline Shareholder's fund & 26.26 & 24.26 & 8.04 & 7.22 & 3.77 \\
\hline Gross earning & 15.00 & 15.29 & 12.86 & 9.72 & 7.92 \\
\hline Profit before tax & 3.13 & 1.00 & 1.42 & 2.28 & 2.29 \\
\hline
\end{tabular}

Source: Wema Bank Presentation at the London Stock Exchange (2007). 
Table 2. Five-year annual financial statements summary of Intercontinental Bank Plc

\begin{tabular}{|c|c|c|c|c|c|c|}
\hline Profitabilitilty ratio & $\begin{array}{c}\text { Post-merger } \\
\text { Feb. } 06 \\
\end{array}$ & $\begin{array}{c}14 \text { months } \\
\text { ended Feb. } 05\end{array}$ & Dec 03 & Dec 02 & Dec 01 & $\begin{array}{c}5 \text { year } \\
\text { average } \\
\end{array}$ \\
\hline Gross earnings & $50.65 \%$ & $41.93 \%$ & $38.82 \%$ & $34.89 \%$ & $32.48 \%$ & $39.75 \%$ \\
\hline Gross earnings/total assets $\&$ contingent liabilities & $9.81 \%$ & $11.42 \%$ & $19.54 \%$ & $6.93 \%$ & $5.41 \%$ & $10.62 \%$ \\
\hline Profit after Tax/ Gross earnings & $21.16 \%$ & $23.89 \%$ & $17.00 \%$ & $17.66 \%$ & $13.22 \%$ & $18.79 \%$ \\
\hline Gross operating margin & $79.57 \%$ & $78.25 \%$ & $65.99 \%$ & $64.62 \%$ & $60.35 \%$ & $69.78 \%$ \\
\hline Net interest margin & $27.21 \%$ & $30.45 \%$ & $21.23 \%$ & $20.48 \%$ & $16.95 \%$ & $23.26 \%$ \\
\hline Return on average assets (pre-tax) & $4.20 \%$ & $5.69 \%$ & $5.69 \%$ & $5.54 \%$ & $4.09 \%$ & $5.04 \%$ \\
\hline Return on equity & $15.96 \%$ & $15.40 \%$ & $29.98 \%$ & $25.30 \%$ & $27.50 \%$ & $22.81 \%$ \\
\hline
\end{tabular}

Source: www. Intercontinentalbankplc.com: Trend in Performance 2001-2006.

Table 3. Regression showing whether Merger/Acquisition has curbed distress in Nigeria Banks

\begin{tabular}{lllll}
\hline Model & Coefficient & Std. Error & T & Sig. T \\
\hline Constant & -9.514 & 2.389 & -3.983 & .000 \\
Merger and Acquisition & .281 & .043 & 6.591 & $.000^{* *}$ \\
\hline
\end{tabular}

Source: Field Survey 2011.

Note: ${ }^{* *}$ means significant results.

Table 4. ' $t$ '-test showing the Banks' performances in pre and post-Merger periods

\begin{tabular}{|c|c|c|c|c|c|c|c|}
\hline Variable & Period & $\mathrm{N}$ & Mean & SD & $\mathrm{t}$-cal & t- tab & Sig. \\
\hline \multirow[t]{3}{*}{ Capital } & Pre-Merger & 5 & 1433.20 & 823.40 & & & \\
\hline & & & & & 6.755 & 2.00 & $.001^{* *}$ \\
\hline & Post-Merger & 5 & 6358.76 & 3551.57 & & & \\
\hline \multirow[t]{3}{*}{ Profit } & Pre-Merger & 5 & 2192.48 & 1847.17 & & & \\
\hline & & & & & 5.276 & 2.00 & $.000^{* *}$ \\
\hline & Post-Merger & 5 & 16839.12 & 13755.78 & & & \\
\hline
\end{tabular}

Source: Financial records of the selected banks (2001-2010).

Note: ${ }^{* *}$ means significant results.

Table 5. Regression on whether bad corporate governance is responsible for Merger/Acquisition

\begin{tabular}{lllll}
\hline Model & Coefficient & Std. Error & T & Sig. T \\
\hline Constant & -7.959 & 18.533 & -.429 & .669 \\
Merger and Acquisition & 1.059 & .331 & 3.197 & $.002^{* *}$ \\
\hline
\end{tabular}

Source: Field Survey 2011.

Note: ${ }^{* *}$ means significant results. 
All values in million

Afrik bank

Pre-Merger

2001

Capital

2002

552

552

552

2003

2004

1104

2005

2354

Post-Merger

2006

2554

2007

2554

2008

2554

3548

2009

5760

Profit

Skye bank Capital

Profit

$116 \quad 500$

203

$2231 \quad 1524$

$2471 \quad 1524$

$1566 \quad 1524$

854

918

$231 \quad 2264$

743

$3695 \quad 3245$

2091

$5081 \quad 3752$

7519

$12361 \quad 5792$

20425

16024

6812

24623

20425

6923

26736

UBA

Pre-Merge

2001

2002

Capital

Profit

Wema bank Capital

Profit

1585

675

800

2238

779

2294

4816

1527

2286

5618

1555

1420

2004

1275

6239

4452

1002

Post-Merger

2006

$12514 \quad 4542$

(7200)

2007

3530

22827

5035

1879

45805

5496

3456

8622

48343

6212

9867

2010

19086

50198

6981

12133

Intercontinental

Pre-Merger

Capital

Profit

2001

1436

1343

2002

1794

1523

2003

1794

2380

2004

1794

3414

2005

1794

6706

Post-Merger

2006

$5362 \quad 11030$

2007

5362

22316

2008

9733

9960

2009

10121

11231

2010

10320

13239

Source: www.google.com.

Compiled from CBN bulletins 2002-2010. 